\title{
Efek Ekstrak Limbah Cair Empulur Batang Sagu Baruk (Arenga microcarpha) Terhadap Fotoreduksi Besi(III)
}

\author{
Haider Ali Ginting a, Johnly Alfreds Rorong a*, Audy D. Wuntu a \\ aJurusan Kimia, FMIPA, Unsrat, Manado
}

\begin{tabular}{l} 
K A T A K UNC I \\
\hline limbah cair \\
sagu baruk \\
fitokimia fenolik \\
fotoreduksi
\end{tabular}

\begin{abstract}
A B S T R A K
Telah dilakukan penelitian untuk menganalisis kandungan fenolik, flavonoid, dan tanin dari limbah cair empulur batang sagu baruk dan menguji kemampuanya dalam fotoreduksi $\mathrm{Fe}^{3+}$. Empulur batang sagu baruk diekstrak dengan pelarut akuades secara maserasi selama 2 jam. Selanjutnya ekstrak hasil maserasi dianalisis kandungan fitokimia fenolik, flavonoid dan tanin dengan menggunakan spektrofotometer UV-Vis. Pengujian fotoreduksi dilakukan pada cahaya fluorescent dengan konsentrasi $1000 \mathrm{mg} / \mathrm{L}$ selama 5 jam dengan variasi $\mathrm{pH}$ 4, 5, 6, 7 dan 8 serta kapasitas daya 42, 62 dan 104 Watt. Analisis ekstrak limbah cair empulur batang sagu baruk menunjukkan konsentrasi fenolik 112,04 mg asam galat/L konsentrasi flavonoid 30,10 mg kuersetin/L dan konsentrasi tanin 22,02 mg katekin/L.Hasil penelitian menunjukkan bahwa ekstrak limbah cair empulur batang sagu baruk pada $\mathrm{pH} 6$ dengan kapasitas daya 104 Watt mempunyai kemampuan yang paling baik untuk mereduksi $\mathrm{Fe}^{3+}$ dibandingkan dengan ekstrak lainya.
\end{abstract}

KE YWOR D S

liquid waste

sago baruk

phenolic phytochemical

photoreduction

\begin{abstract}
A B S T R A C T
Research had been carried out to analyze the photochemicals phenolic, flavonoids, and tanins in liquid waste of pith trunk sago baruk and to test its ability in photoreduction. Pith trunk extracted with aquadest in maceration for two hours. The extracts resulted were then analyzed for phenolic, flavonoids and tanins phytochemicals using spectrophotometer UV-Vis. The photoreduction tests performed on fluorescent light with concentration of $1000 \mathrm{mg} / \mathrm{L}$ for five hours with variation $\mathrm{pH} \mathrm{4,} \mathrm{5,} \mathrm{6,} 7$ and 8 and on energy capacities of 42, 62 dan 104 Watt. Analysis of liquid waste of pith trunk sago baruk extract showed that phenolic concentration was $112,04 \mathrm{mg}$ gallic acid/L, flavonoid concentration was $30,10 \mathrm{mg}$ quersetin/L and tannin concentration was $22,02 \mathrm{mg}$ chatechin/L. The results showed that extract liquid waste pith trunk sago baruk at pH 6 with energy capacities 104 Watt had best ability in photoreduction $\mathrm{Fe}^{3+}$.
\end{abstract}

TERSEDIA ONLINE

20 Maret 2016 salah satunya ialah limbah cair dari proses pengolahan empelur batang sagu baruk.

Sagu merupakan jenis bahan pangan yang banyak tumbuh di daerah Indonesia bagian Timur termasuk Sulawesi Utara yang pada umumnya dimanfaatkan sebagai bahan pangan tradisional. Sagu memiliki kandungan gizi antara lain karbohidrat, protein, serat, kalsium, besi , lemak, karoten, dan asam askorbat (Haryanto dan Pangloli,

*Corresponding author: Jurusan Kimia FMIPA UNSRAT, Jl. Kampus Unsrat, Manado, Indonesia 95115; Email address: rorongjohnly@yahoo.co.id Published by FMIPA UNSRAT (2016) 
1992). Ada beberapa jenis tanaman sagu, salah satu jenis tanaman sagu yang memiliki potensi cukup besar untuk dikembangkan sebagai sumber bahan pangan adalah sagu baruk (Arenga microcarpha). Dari hasil pengolahan sagu baruk menghasilkan limbah berupa ampas sagu dan limbah cair.

Menurut Tahir (2004), ekstrak empelur, limbah empelur dan limbah cair sagu (Metroxylon sagu Rottb) memiliki aktivitas antioksidan dan tidak toksik. Dari hasil penelitian Talapessy et al. (2013) menunjukkan bahwa kandungan fenolik dari ekstrak ampas hasil pengolahan sagu (Metroxylon sagu Rottb) dengan pelarut etanol $40 \%$ mempunyai kandungan total fenolik paling tinggi, diikuti dengan pelarut etanol: 20; 60 dan $80 \%$.

Pada umumnya tumbuhan mengambil besi dalam bentuk ion $\mathrm{Fe}^{2+}$ namun ketersediaan besi di alam dalam bentuk ion $\mathrm{Fe}^{3+}$ sehingga perlu direduksi. Namun tingkat oksidasi dan banyaknya spesies besi berada dalam larutan merupakan fungsi $\mathrm{pH}$ sehingga pada $\mathrm{pH}$ di atas 7 akan mengurangi ketersediaan dan kelarutan besi yang mengakibatkan terjadinya defisiensi besi pada tumbuhan (Blesa dan Matijevic, 1989). Menurut Wittbrodt dan Palmer (1995), reduksi Cr(VI) menjadi $\mathrm{Cr}$ (III) bergantung pada konsentrasi awal $\mathrm{Cr}(\mathrm{VI})$ dan $\mathrm{pH}$ larutan. Sedangkan menurut Eary dan Ray (1991), reduksi $\mathrm{Cr}(\mathrm{VI})$ dalam tanah subpermukaan menjadi lebih cepat pada kondisi $\mathrm{pH}$ yang lebih asam.

Tujuan penelitian ini adalah mempelajari pengaruh varisi $\mathrm{pH}$ dan kapasitas daya untuk fotoreduksi besi.

\section{Material dan Metode}

Sampel yang digunakan pada penelitian ini adalah limbah cair dari empulur batang sagu baruk yang berasal dari kepulauan sangihe. Bahan kimia yang digunakan yaitu natrium karbonat, reagen Folin-Ciocalteau, vanilin, alumunium klorida, asam klorida, natrium hidroksida, buffer fosfat, 2,2 bipiridin $0,07 \%$, larutan ion logam $\mathrm{Fe}^{3+}$ yang diperoleh dari Merck (Darmstat, Germany) serta akuades. Peralatan yang digunakan dalam penelitian ini adalah mikropipet, vorteks, oven Mammert, rotary vacuum evaporator Eyela N-1000, ruang penyinaran berukuran $70 \times 50 \times 60 \mathrm{~cm}$ yang dilengkapi dengan cahaya flourescen 42, 62 dan 104 watt Phillips cool white, spektrofotometer UVVis Thermo Scientific Genesys 20.

\subsection{Ekstraksi}

Sebanyak $100 \mathrm{~g}$ empulur sagu baruk ditambahkan dengan $200 \mathrm{~mL}$ akuades dihaluskan menggunakan alat blender selama 5 menit dan didiamkan, selanjutnya disaring dengan kain saring sehingga diperoleh filtrat dan ampas. Ampas sagu baruk di tambahkan $200 \mathrm{~mL}$ akuades di haluskan selama 5 menit, disaring dan di diamkan. Hal serupa dilakukan sampai 3 kali ekstraksi.
Selanjutnya filtrat diuapkan dengan rotary evaporator untuk mendapatkan ekstrak pekat limbah cair sagu baruk.

\subsection{Penentuan Kandungan Total Fenolik, Flavonoid dan Tanin}

Penentuan kandungan total fenolik ekstrak limbah cair empulur batang sagu baruk dengan menggunakan metode Folin-Ciocalteau. Absorbansi ekstrak dibaca pada spektrofotometer visibel dengan $\lambda 750 \mathrm{~nm}$. Kandungan total fenolik dinyatakan sebagai $\mathrm{mg}$ ekivalen asam galat/L ekstrak (Conde et al., 1997). Penentuan kandungan total flavonoid ekstrak limbah cair empulur batang sagu baruk ditentukan menurut metode Meda et al. (2005). Absorbansi dibaca $\lambda 415 \mathrm{~nm}$. Kandungan total flavonoid dinyatakan sebagai $\mathrm{mg}$ ekivalen kuesertin/kg ekstrak. Penentuan kandungan total tanin ekstrak limbah cair empulur batang sagu baruk ditentukan menurut metode Julkenen-Tito (1985). Absorbansi dibaca pada $\lambda 500 \mathrm{~nm}$. Kandungan total tanin terkondensasi dinyatakan sebagai mg ekivalen ketekin/L ekstrak.

\subsection{Efek $\mathrm{pH}$ Terhadap Fotoreduksi Ekstrak Limbah Cair Empulur Batang Sagu Baruk}

Ekstrak limbah cair empulur batang sagu baruk pada konsentrasi $1000 \mathrm{mg} / \mathrm{L}$ dibuat pada $\mathrm{pH} \mathrm{4,} \mathrm{5,}$ 6, 7 dan 8. $\mathrm{pH}$ diatur dengan penambahan $\mathrm{NaOH} 1$ $\mathrm{N}$ dan $\mathrm{HCl} 1 \mathrm{~N}$, dengan buffer fosfat untuk mempertahankan $\mathrm{pH}$ yang telah diatur. Selanjutnya ekstrak diinteraksikan dengan $20 \mathrm{~mL}$ larutan ion logam $\mathrm{Fe}^{3+}$ pada konsentrasi $25 \mathrm{mg} / \mathrm{L}$ yang dilarutkan di dalam akuades. Sampel diambil sebanyak $20 \mathrm{~mL}$ dan dimasukkan ke dalam botol serum berukuran $25 \mathrm{~mL}$ kemudian botol ditutup dengan sumbat karet. Sampel tersebut diletakkan ke dalam kotak cahaya fluorescent berdaya 62 watt selama 5 jam, cuplikan diambil sebanyak 5 kali yaitu $0,1,2,3$ dan 5 jam. Setelah selesai penyinaran, dilakukan analisis kadar besi tereduksi.

\subsection{Efek Jumlah Daya Terhadap Fotoreduksi Ekstrak Limbah Cair Empulur Batang Sagu Baruk}

Ekstrak limbah cair empulur batang sagu baruk dari hasil yang terbaik dari penelitian 3.3.4 selanjutnya diinteraksikan dengan $20 \mathrm{~mL}$ larutan ion logam $\mathrm{Fe}^{3+}$ pada konsentrasi $25 \mathrm{mg} / \mathrm{L}$ yang dilarutkan di dalam akuades. Sampel diambil sebanyak $20 \mathrm{~mL}$ dan dimasukkan ke dalam botol serum berukuran $25 \mathrm{~mL}$ kemudian botol ditutup dengan sumbat karet. Sampel tersebut diletakkan ke dalam kotak cahaya fluorescent berdaya 42, 62, dan 104 watt selama 5 jam, cuplikan diambil sebanyak 5 kali yaitu 0, 1, 2, 3 dan 5 jam. Setelah selesai penyinaran, dilakukan analisis kadar besi tereduksi. Interaksi dari limbah cair empelur batang sagu baruk dengan besi dievaluasi efeknya terhadap fotoreduksi ion $\mathrm{Fe}^{3+}$. Sebanyak $2 \mathrm{~mL}$ sampel ditambahkan dengan $0,5 \mathrm{~mL}, 2,2$ bipiridin $0,07 \%$ dan divorteks selama 2 menit. Absorbansi sampel dibaca pada $\lambda 520 \mathrm{~nm}$ dengan menggunakan spektrofotometer UV-Vis pada suhu 
ruang. Kandungan besi yang tereduksi dinyatakan sebanyak $\mathrm{mg} / \mathrm{L}$ untuk kurva kalibrasi menggunakan $\mathrm{NH}_{4} \mathrm{Fe}^{2+}\left(\mathrm{SO}_{4}\right)_{2} .6 \mathrm{H}_{2} \mathrm{O}$ sebagai standar.

\section{Hasil dan Pembahasan}

\subsection{Kandungan Total Fenolik, Flavonoid dan Tanin}

Hasil ekstraksi limbah cair empulur batang sagu baruk pada konsentrasi 1000 mg/Ldiuji kandungan fenolik, flavonoid dan tanin. Hasil analisis kandungan total fenolik, flavonoid dan tanin yang diperoleh dapat dilihat pada Gambar 1.

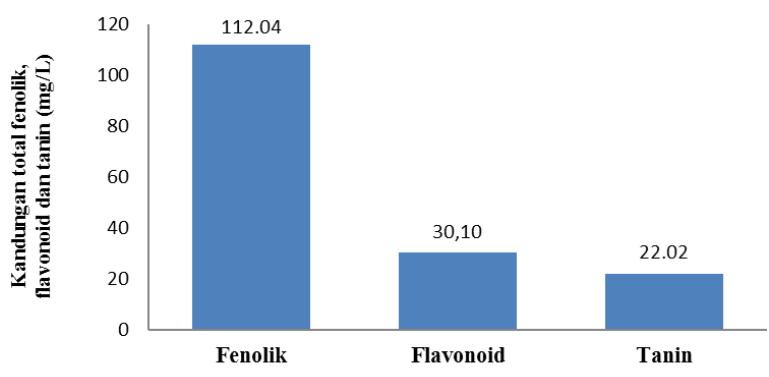

Gambar 1. Kandungan fitokimia ekstrak limbah cair dari empulur batang sagu baruk

Dari Gambar 1 kandungan total fenolik, flavonoid dan tanin menunjukkan bahwa kandungan total fenolik dari eksrak limbah cair empulur batang sagu baruk mempunyai konsentrasi paling tinggi yaitu $112,04 \mathrm{mg} / \mathrm{L}$ diikuti oleh flavonoid 30,10 mg/L dan tanin 22,02 mg/L.

Kandungan total fenolik dalam ekstrak limbah cair empulur batang sagu baruk ditentukan dengan menggunakan metode Folin-Ciocalteu berdasarkan kemampuan senyawa fenolik dalam ekstrak limbah cair empulur batang sagu baruk bereaksi dengan asam fosfomolibdat-fosfotungstan dalam reagen folin-ciocalteu (kuning) yang akan mengalami perubahan warna menjadi biru, semakin tua intensitas warna yang dihasilkan maka total kandungan senyawa fenolik dalam ekstak semakin besar (Sahidi dan Nazk, 1995). Menurut Singelton dan Rosi (1965), semakin pekat warna biru yang dihasilkan maka semakin besar ion fenolat terbentuk yang berbanding lurus dengan konsentrasi fenolik.

Penentuan kandungan total flavonoid dinyatakan sebagai ekivalen kuersetin dalam $\mathrm{mg} / \mathrm{L}$ ekstrak. Berdasarkan analisis yang telah dilakukan kandungan total flavonoid dari ekstrak limbah cair empulur batang sagu baruk sebesar 30,10 mg/L. Analisis kandungan flavonoid dilakukan dengan menambahkan $\mathrm{AlCl}_{3}$ yang dapat membentuk kompleks asam yang stabil dengan gugus keto dan gugus hidroksil pada flavon atau flavonol (Robinson, 1995). Kandungan total tanin terkondensai pada ekstrak limbah cair empulur batang sagu baruk yang di nyatakan dalam miligram katekin per liter ekstrak adalah yang terkecil yaitu 22,02 mg/L dibandingkan dengan kandungan total fenolik dan flavonoid.
Menurut Barlett et al. (2001) flavonoid merupakan komponen organik yang dapat melindungi sel dari senyawa oksigen reaktif (ROS) dan berfungsi juga sebagai agen pengkhelat Fe hal ini di karenakan flavonoid mempunyai gugus karboksil dan satu gugus fenolik atau dua gugus karboksil yang berdekatan yang dapat bereaksi dengan ion Fe menghasilkan kompleks yang stabil.

\subsection{Efek pH Ekstrak Limbah Cair Empulur Batang Sagu Baruk terhadap Fotoreduksi $\mathrm{Fe}^{3+}$}

Hasil analisis Gambar 2 menunjukkan bahwa $\mathrm{pH}$ berpengaruh pada persentase reduksi $\mathrm{Fe}^{3+}$ dengan variasi $\mathrm{pH}$ yang digunakan adalah 4, 5, 6, 7 dan 8. Dari gambar $2 \mathrm{pH}$ optimum ekstrak limbah cair empulur batang sagu baruk ialah pada $\mathrm{pH} 6$ dengan konsentrasi $\mathrm{Fe}^{2+}$ yang diperoleh selama 5 jam adalah 29,33 mg/L. Hal ini disebabkan pada $\mathrm{pH}$ asam dan netral, spesies besi berada sebagai $\mathrm{Fe}^{2+}$ dan $\mathrm{FeOH}^{+}$sedangkan pada $\mathrm{pH}$ basa $\mathrm{Fe}^{2+}$ dan $\mathrm{FeOH}^{+}$akan menunjukkan pengurangan konsentrasi dan pada $\mathrm{pH}$ diatas 10 , keberadaan $\mathrm{Fe}^{2+}$ dan $\mathrm{FeOH}^{+}$ sudah tidak ada dalam larutan (Blesa dan Matijevic, 1989).

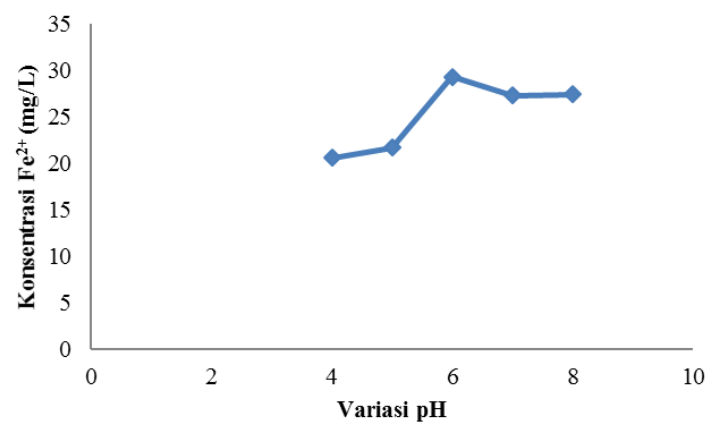

Gambar 2. Efek pH terhadap fotoreduksi $\mathrm{Fe}^{3+}$ setelah dicahayai selama 5 jam

Selain itu $\mathrm{pH}$ juga berfungsi dalam menentukan spesies besi dalam larutan sehingga lebih mudah dikhelat dan distabilkan oleh komponen organik dari ekstrak limbah cair empelur batang sagu baruk. Skogerboe dan Wilson (1981), menyatakan bahwa reduksi $\mathrm{Hg}(\mathrm{II})$ akan lebih cepat pada kondisi asam karena pada kondisi $\mathrm{pH}$ rendah senyawa fenolik berada sebagai $-\mathrm{OH}^{+}$dan pada kondisi asam senyawa fenolik lebih mudah diprotonasi untuk meningkatkan karakter pereduksinya.

\subsection{Efek Daya terhadap Fotoreduksi $\mathrm{Fe}^{3+}$ pada Ekstrak Limbah Cair Empelur Batang Sagu Baruk}

Dari gambar 3 menunjukkan bahwa ekstrak yang disinari dengan daya 104 Watt memiliki konsentrasi $\mathrm{Fe}^{2+}$ paling tinggi yaitu $31,12 \mathrm{mg} / \mathrm{L}$ diikuti dengan ekstrak yang disinari dengan daya 62 Watt yaitu 29,33 mg/L Watt dan ekstrak yang disinari dengan daya 42 watt yaitu $26,20 \mathrm{mg} / \mathrm{L}$. 


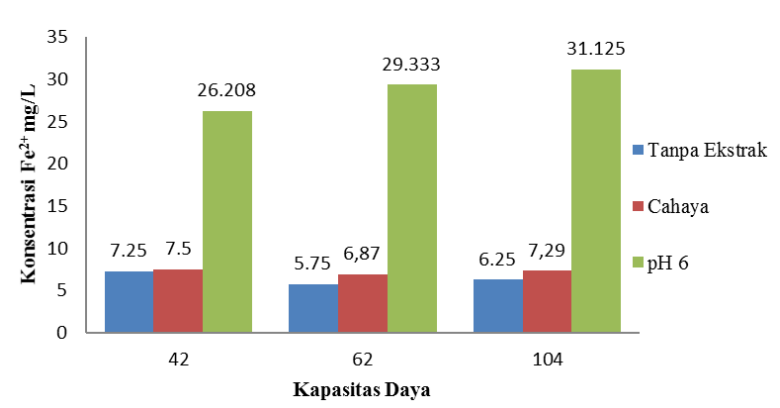

Gambar 3. Efek ekstrak limbah cair empulur batang sagu baruk dengan variasi kapasitas daya terhadap fotoreduksi $\mathrm{Fe}^{3+}$ setelah disinari lampu fluorescent selama 5 jam.

Kemampuan terbesar fotoreduksi $\mathrm{Fe}^{3+}$ pada daya 104 Watt di duga disebabkan oleh energi yang dihasilkan untuk mengeksitasi elektron lebih besar sehingga ekstrak yang mempuyai kandungan fenolik memerlukan lebih sedikit energi untuk mengeksitasi elektronnya dibandingkan dengan kapasitas daya 62 dan 42 Watt. Menurut Fesenden dan fesenden (1997) panjang gelombang ultraviolet (UV) atau cahaya tampak bergantung pada mudahnya eksitasi elektron. Molekul - molekul yang memerlukan lebih banyak energi untuk mengeksitasi elektronnya akan menyerap pada panjang gelombang yang lebih pendek, sedangkan pada panjang gelombang yang lebih panjang molekul-molekul memerlukan energi yang lebih sedikit untuk mempromosikan elektronnya (Saragih, 2002). Hasil analisa regresi antara kapasitas daya dan konsentrasi $\mathrm{Fe}^{2+}$ didapatkan persamaan linear $y=0,073 x+23,78$ dengan nilai $R^{2}=0,877$. Perhitungan koefesien korelasi antara kapasitas daya dan konsentrasi $\mathrm{Fe}^{2+}$ didapat nilai 0,937.

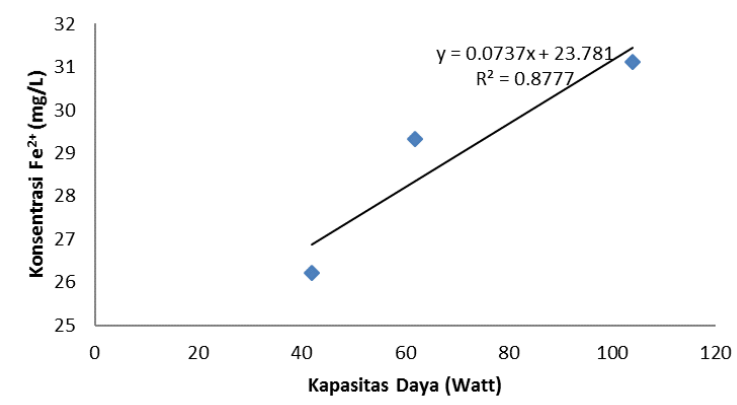

Gambar 4. Kurva hubungan variasi kapasitas daya terhadap fotoreduksi $\mathrm{Fe}^{3+}$.

Namun secara statistika hubungan antara kapasitas daya dengan konsentrasi $\mathrm{Fe}^{2+}$ atau antara kedua variabel tidak berarti atau signifikan hal ini ditunjukkan oleh $r$ hitung lebih kecil dari pada $r$ tabel yaitu $r($ hit $)=0,937<r($ tab $)=0,996$ pada tingkat kesalahan $5 \%$ walaupun pada kurva regresi terlihat nilai variabel $\mathrm{Y}$ (konsentrasi $\mathrm{Fe}^{2+}$ ) dipengaruhi oleh variabel $X$ (kapasitas daya) dan berdasarkan nilai uji hipotesis korelasi, kedua variabel tersebut tidak memiliki korelasi berarti hal ini ditunjukkan oleh nilai t hitung lebih kecil dari pada $\mathrm{t}$ tabel yaitu $\mathrm{t}(\mathrm{hit})=2,38<\mathrm{t}(\mathrm{tab})=6,31$ sehingga dapat disimpulkan bahwa kapasitas daya tidak dapat sepenuhnya meningkatkan karakter dari senyawa fenolik untuk mereduksi $\mathrm{Fe}^{3+}$. Namun demikian, dari kurva regresi tersebut terlihat adanya sedikit kecendrungan bahwa semakin besar kapasitas daya yang digunakan, semaikin tinggi konsentrasi $\mathrm{Fe}^{2+}$ yang dihasilkan. Hal ini dapat dilihat dari nilai a (sudut persamaan regresi) yang bernilai positif $(+0,073)$.

\section{Kesimpulan}

Berdasarkan hasil penelitian dapat disimpulkan bahwa variasi $\mathrm{pH}$ dan kapasitas daya diindikasikan dapat meningkatkan karakter atau kemampuan ekstrak limbah cair empulur batang sagu baruk dalam mereduksi $\mathrm{Fe}^{3+}$.

\section{Daftar Pustaka}

Blesa, M. A., dan E. Matijevic. 1989. Characterization of New Iron Oxides, Terjemahan Bhratara Karya Asara. Jakarta.

Conde, E., E. Cadahia, M.C.G. Vallejo, B.F.D. Simon, dan J.R.G. Adradros. 1997. Low Molecular Weight Polyphenol in Cork of Qoercus Suber. Journal of Agriculture Food Chemistry. 45: 2695-2700.

Eary, I. F., dan Ray. D. 1991. Chromate Reduction by Subsurface Soils Under Acidic Conditions. Journal Soil Scient. 55 : 618-620.

Fesenden, R.J., dan J.S. Fesenden. 1997. Kimia Organik. Edisi ketiga. Jilid 2. Erlangga, Jakarta.

Haryanto, B., dan P. Pangloli. 1992. Potensi dan Pemanfaatan Sagu. Kansius. Jakarta

Julkenen-Titto, R. 1985. Phenolic Constituents in the Leaves of Northern Willows: Methods for the Analysis of Certain Phenolic. Journal of Agriculture Food Chemistry. 33: 213-217.

Meda, A., C.E. Lamien, M. Romito, J. Milliogo, dan O.G. Nacoulina. 2005. Determination of the Total Phenolic, Flavonoid and Proline Content in Burkina Fasan Honey, as well as Their Radical Scavenging Activity. Journal of Food Chemistry. 91: 571-577.

Nely, F. 2007. Aktivitas Antioksidan rempah Pasar dan Bubuk rempah pabrik dengan metode Polifenol dan uji AOM (Active Oxygen Method). Institud Teknologi bogor, Bogor.

Rorong, J. A., Sudiarso, B. Prasetya, J.P. Mandang, dan E. Suryanto. 2012. Analisis Fitokimia Limbah Pertanian Daun Cengkih (Eugenia aromatica) Sebagai Biosensitizer Untuk Fotoreduksi Besi. Prosiding Seminar Nasional Kimia UNESA; Surabaya, 25 Febuari 2012. Himpunan Kimia Indonesia. HIm 341-344.

Saragih, B.C. 2002. Isolasi Asam Humat dan Aplikasinya Sebagai Sensitizer Dalam Fotoreduksi $\mathrm{Fe}(\mathrm{III})$. Tesis Program Pasca Sarjana. UGM, Yogyakarta. 
Shahidi, F., dan M. Naczk. 1995. Food Phenolics: Sources, Chemistry, Effects and Application. Technomic Publishing Co. Inc., Lancaster-Basel.

Singelton, V. L., dan J. A. Rossi. (1965). Calorimeter of total phenolic with phosphomolibdicphosphotungstic acid reagents. American Journal of Enology and Viticulture. 16 : 144158.

Skogerboe, R. K., dan S. A. Wilson. 1981. Reduction of Ionic Species by Fulvic Acid. Journal Analysis Chemistry. 53: 228-232.
Tahir, N.I.M. 2004. Extraction dan Screening of Antioxidants in Metroxylon sagu. Thesis. Biotechnology Progamme, School of Science \& Technology. Universiti Malaysia Sabah.

Talapessy, S., E. Suryanto, dan A. Yudistira. Uji Aktivitas Antioksidan dari Ampas Hasil Pengolahan Sagu (Metroxylon sagu Rottb). Jurnal IImiah Farmasi. 2 (3): 40-44.

Witbrodt, P. R dan Palmer. C. D. 1995. Reduction of $\mathrm{Cr}(\mathrm{VI})$ in the Presence of Excess Soil Fulvic Acid. Journal Environment Scient Technology. 29:255-263 